\title{
Impact of Integration and Globalization on Business Risk and loans in Slovak Agriculture
}

\author{
Marian Toth ${ }^{1}$, Tomas Rabek $^{1}$ and Zuzana Strapekova ${ }^{1}$ \\ ${ }^{1}$ Slovak University of Agriculture in Nitra, Faculty of Economics and Management, Department of \\ Finance, Tr. A Hlinku 2, 94976 Nitra, Slovakia
}

\begin{abstract}
The paper evaluates the effects of integration and globalization on individual farms in Slovakia after EU accession in 2004. The decrease in employment in agriculture is a result of technological progress, changes in individual family preferences and low income in agriculture in comparison to other sectors of economy. In the production commodities with low labor input dominate. Cereals, oilseeds and industrial crops dominate the agriculture production in Slovakia. Large farms benefit in form of economy of scale and agricultural output of farms remains low in Slovakia. The paper compares the risk of crop and animal production based in individual farm data using Markowitz portfolio theory. The crop production is more risky due to higher effects of weather condition compared to animal production. The second part of the paper evaluates the changes on access to credit and finance gap of farms in Slovakia. Based on individual interviews with representatives of demand and supply of loans the paper concludes that large the Common agricultural policy is playing a dominant role in access to credit. Banks consider the CAP subsidies to be a stable income factor and good collateral for loans. The loan market is dominated by short term loans and the majority of the market offers are coming from 4 commercial banks. The finance gap exists towards small farmers and farmers with animal production and special crops.
\end{abstract}

\section{Introduction}

Farming is generally a risky business (1). This is due to the combination of environmental conditions, unpredictable economic shocks, and consequently, the financial situation of farm. Additionally the higher risk increases the financial risk resulting in lack of external funding. Financial intermediaries, especially banks, are risk averse and therefore the higher risk of the borrower results in credit constraints.

Limited use of improved technologies has been identified as a major factor contributing to low agricultural productivity in developing countries (2).The limited access to adequate credit for farmers to purchase improved inputs remains a major challenge in the agricultural production process $(2,3)$. Adequate access to credit has the potential to impact technology adoption, thereby improving agricultural productivity and sustainable agricultural intensification (2).

Rural development and, in particular, farm productivity, can be influenced by several factors; one is access to credit. Access to credit may affect farm productivity because 
farmers facing binding capital constraints would tend to use lower levels of inputs in their production activities compared to those not constrained. Improved access to credit may therefore facilitate optimal input use and have a major impact on productivity. Thus, access to credit allows farmers to satisfy their cash needs induced by the agricultural production cycle and consumption requirements (4).

In transition economies access to credit increases the total factor productivity up to 1.9 percent per 1,000 EUR of additional credit, indicating that an improved access to credit results in adjusting the relative input intensities on farms. This finding is further supported by a negative effect of better access to credit on labour, suggesting that these two are substitutes (5). Credit markets work imperfectly even in countries with a developed market economy and government intervention (6).

The paper analyses risk and access to credit in Slovak agriculture based on individual farm data and interviews with main finance providers and farmer's organisations in Slovakia.

\section{Methodology}

The data used for the analysis are from the database of Ministry of Agriculture and Rural Development of the Slovak Republic. The modified Markowitz portfolio theory approach was used to estimates the total risk of five portfolios consisting of all agricultural farms, capital companies, cooperatives, crop farm and animal farms. We assumed that the return of the investor is based on the profit of the company and the equity invested. Therefore, we considered return on equity ROE (Eq. 1) to be equivalent to the return on stocks, generally used in the case of quoted companies. Measuring volatility of return in the Markowitz portfolio theory is based on the average return over the observed period for each investment. We calculated the average return on equity EROEi (Eq. 2) for each individual farm.

$$
\begin{gathered}
R O E_{i}=\frac{\text { Earnings After Taxes }}{\text { Sharesholders Equity }} \\
E_{R O E_{i}}=\sum_{i=1}^{t} R O E_{i} \cdot d_{i}
\end{gathered}
$$

Where ROEi is return on equity of farm "i", di is a weight of ROEi over the observed period ( 5 years, $\mathrm{di}=0.20)$, $\mathrm{t}$ is number of years in observed period, $\mathrm{i}, \mathrm{j}$ are individual farms. The individual risk of each farm $\left(\sigma_{i}\right)$ is calculated using the standard deviation.

$$
\sigma_{i}=\sqrt{\sum_{i=1}^{t}\left(R O E_{i}-E R O E_{i}\right)^{2} \cdot d_{i}}
$$

Where $\sigma \mathrm{i}$ is standard deviation of the individual return on equity (individual farm risk), ROEi is individual return on equity, EROEi is average individual return on equity.

The portfolio risk is determined by three variables: weight of the individual investment in portfolio (wi), standard deviation of the individual investment - individual risk ( $\sigma \mathrm{i})$, and covariance, relation between the ROEi and $\mathrm{ROEj}(\sigma \mathrm{ij})$. To take into account market portfolio of all agriculture farms, the weight wi of each farm is determined by farm market share, which is the share of the farm' $\mathrm{s}$ equity on the total equity of all farms. The covariance represents the relationship between returns on equity of farms (Eq 4) and $\Sigma$ covariance matrix (Eq. 5). The portfolio risk is then measured according to eq. 6 


$$
\begin{aligned}
& \sigma_{i j}=\frac{1}{n} \sum_{i=1}^{n}\left(R O E_{i}-E R O E_{i}\right)\left(R O E_{j}-E R O E_{j}\right) \\
& \Sigma=\left[\begin{array}{ccccc}
\sigma_{11} & \sigma_{12} & \sigma_{13} & \ldots & \sigma_{1 \mathrm{k}} \\
\sigma_{21} & \sigma_{22} & \sigma_{23} & \ldots & \sigma_{2 \mathrm{k}} \\
\sigma_{31} & \sigma_{32} & \sigma_{33} & \ldots & \sigma_{3 \mathrm{k}} \\
& \ldots & & \\
\sigma_{\mathrm{k} 1} & \sigma_{\mathrm{k} 2} & \sigma_{\mathrm{k} 3} & \ldots & \sigma_{\mathrm{kk}}
\end{array}\right] \\
& \sigma_{p}=\sqrt{\sum_{i=1}^{n} w_{i}^{2} \cdot \sigma_{i}^{2}+\sum_{i=1}^{n} \sum_{j=1}^{n} w_{i} \cdot w_{j} \cdot \sigma_{i j}}
\end{aligned}
$$

Where wi is an individual weight of i-farm (farm`s equity) in a portfolio (total equity of all farms) and $\mathrm{n}$ is number of farms.

The expected return on equity of portfolio is estimated by the multiplication of $\mathrm{k} x 1$ vector of individual weights of portfolio (w) and $\mathrm{k} \mathrm{x} 1$ vector of corresponding individual expected returns on equity (the sum of multiplication of each farm's expected ROE and its share in the market portfolio).

$$
\operatorname{EROE}_{p}=\sum_{i=1}^{n} \operatorname{EROE}_{i} \cdot w_{i}
$$

Where EROEp is expected portfolio return on equity and EROEi is the average return on equity of individual farm.

\section{Results}

The accession of the Slovak Republic to the EU and the application of the Common Agricultural Policy (CAP) resulted in reducing risk of agriculture.

Table 2. Development of profitability and risk of farms in Slovakia

\begin{tabular}{|l|r|r|r|r|r|r|r|r|r|r|}
\hline Period & 1 & 2 & 3 & 4 & 5 & 6 & 7 & 8 & 9 & 10 \\
\hline Profitability & -0.4 & -0.02 & 0.18 & 0.67 & 1.99 & 0.45 & 0.2 & 0.93 & 0.78 & 0.08 \\
\hline $\begin{array}{l}\text { Systemic } \\
\text { risk }\end{array}$ & 2.61 & 2.64 & 2.26 & 1.91 & 1.00 & 3.61 & 3.41 & 3.4 & 2.99 & 2.62 \\
\hline
\end{tabular}

Source: Own calculations

\subsection{Volume of the loans in agriculture}

Adoption of CAP did also contribute to a significant increase of bank loans since 2004.Between 2009 and 2013, the volume of funds did not increase due to the financial and economic crisis. But after 2014 banks did eased the credit standards that resulted in combination with increased support from CAP to an increase of outstanding loans for agriculture in Slovakia.

Increase was not proportional across all types of loans based on maturity. Single Area Payment Scheme, which is the main part of the CAP I. Pillar budget in Slovakia, in 
Combination with Greening subsidies led to a significant increase in short-term loans. In 2018, operations and investments of farms were supported with bank loans with outstanding volume 746 mil. EUR. Compared to 2017 the volume increased by $4,7 \%$ annually. The total amount of short-term loans was 306 mil., medium-term loans 171 mil. EUR and long-term loans 269 mil. EUR. The share outstanding loans in agriculture in total outstanding loans in Slovakia reached $1.38 \%$ in 2018. Compared to the year of accession to EU in 2004 the total outstanding loans increased more than 330\% in 2018 (Table 2).

Table 2. Outstanding loans in agriculture in Slovakia (in thousand EUR)

\begin{tabular}{|c|c|c|c|c|c|}
\hline Year & TOTAL loans & Short-term & Medium-term & Lend-term & Failed loans \\
\hline 2004 & 221,566 & 103,084 & 71,315 & 47,167 & n.a. \\
\hline 2005 & 286,261 & 118,801 & 107,234 & 60,226 & 25,892 \\
\hline 2006 & 289,470 & 129,399 & 92,952 & 67,118 & 25,855 \\
\hline 2007 & 322,363 & 135,994 & 100,988 & 85,382 & n.a. \\
\hline 2008 & 413,965 & 176,091 & 121,612 & 116,263 & n.a. \\
\hline 2009 & 395,589 & 139,779 & 139,160 & 116,650 & n.a. \\
\hline 2010 & 380,967 & 190,113 & 92,001 & 98,853 & n.a. \\
\hline 2011 & 414,304 & 202,924 & 91,300 & 120,080 & n.a. \\
\hline 2012 & 401,470 & 201,501 & 80,764 & 119,205 & 9,998 \\
\hline 2013 & 425,934 & 212,435 & 103,273 & 110,226 & 28,865 \\
\hline 2014 & 477,082 & 239,946 & 92,232 & 144,904 & 28,727 \\
\hline 2015 & 543,230 & 272,931 & 101,993 & 168,306 & 32,667 \\
\hline 2016 & 650,314 & 274,900 & 146,220 & 229,194 & 35,144 \\
\hline 2017 & 712,432 & 286,364 & 170,756 & 255,312 & 45,499 \\
\hline 2018 & 746,082 & 306,130 & 170,569 & 269,383 & 42,358 \\
\hline
\end{tabular}

Source: National Bank of Slovakia, own processing

Short-term loans are the most demanded loans by farms. They have low interest rates and are offered by banks with collateral in form of subsidies from CAP. Banks set the volume limit based on the subsidies to be received in the year from the I. Pillar. Short term loans have the share $41 \%$ in total loans in agriculture. (Fig. 1)

Medium-term loans $(23.0 \%)$ with a maturity of one to five years had the lowest share in the loan structure. Compared to 2017 medium-term loans did not increase but did increase in previous years.

Long-term loans with maturities of more than 5 years had a share in total outstanding loans $36 \%$. The increase in medium-term and long-term loans can be attributed to investments in long-term tangible assets as a contribution to the financing of the RDP projects 2014-2020 or the purchase of farms which has been increasing in recent years in Slovakia. 


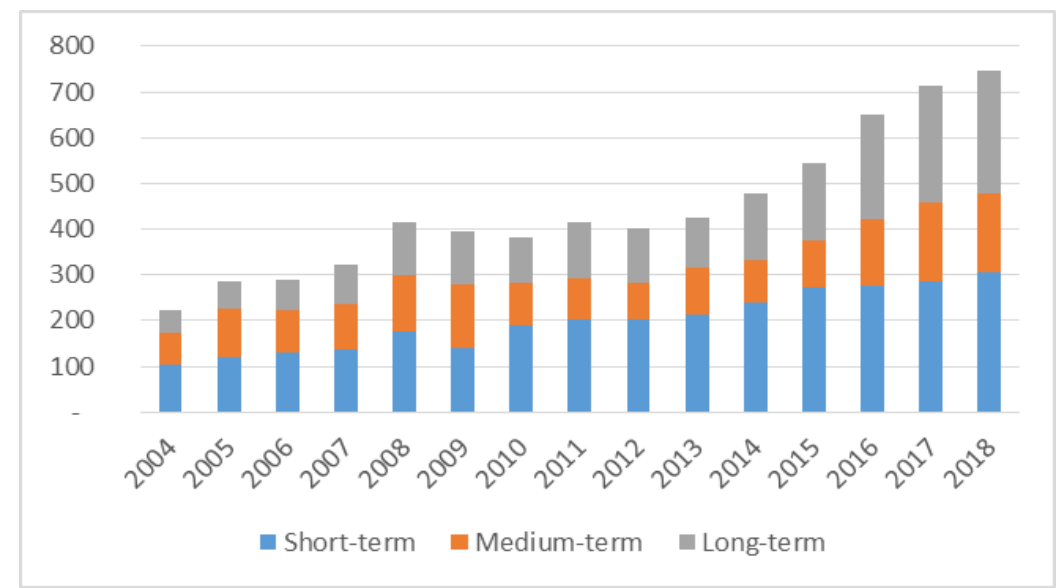

Fig. 1. Development and maturity structure of loans in Slovak agriculture (in mil. EUR)

Banks link the repayment of loans to the period when farms receive subsidies. The majority of subsidies farmers collect in December. Therefore there is a huge discrepancy in outstanding loans between end of November and end of December. Volume of loans in November is significantly higher when compared to December (Fig. 2).

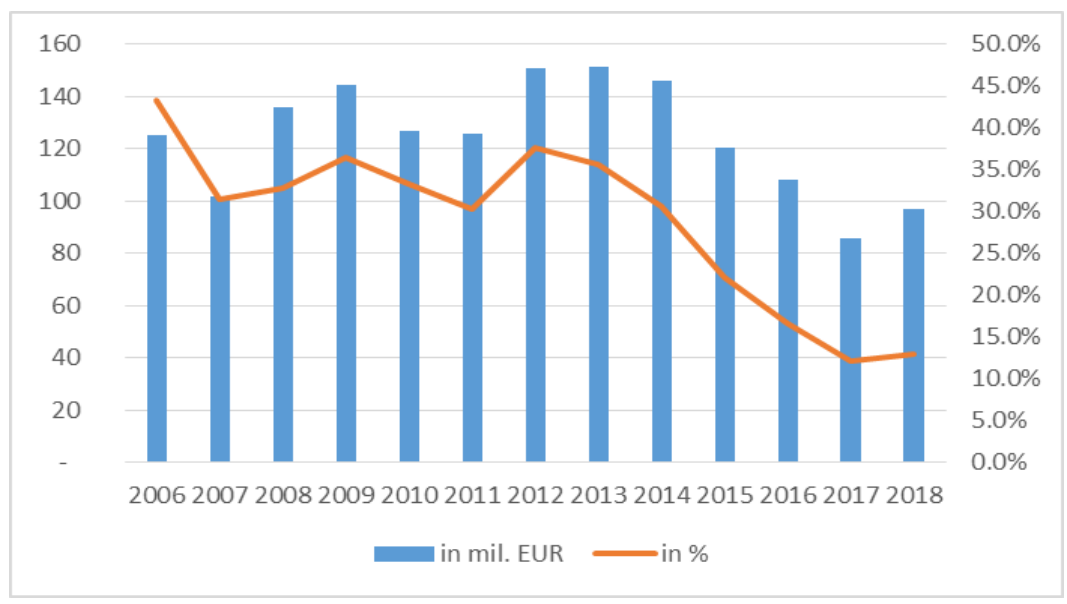

Fig. 2. How much are outstanding loans in November compared to December?

\subsection{Importance of loans in financing farms in Slovakia}

Bank loans are important for farmers in Slovakia. They form $11.1 \%$ of liabilities and owner's equity in Slovakia while the share of subsidies is $8.4 \%$ (Table 3). Based on national data, farmers in Slovakia acquire new fixed assets from owner's equity by $66 \%$, bank loans by $26 \%$ and the rest is covered from subsidies and other funds (Table 4 ). 
Table 3. Structure of funds to finance farm assets in Slovakia

\begin{tabular}{|c|c|c|c|}
\hline & 2015 & 2016 & 2017 \\
\hline Owner's equity & $44.8 \%$ & $44.4 \%$ & $44.8 \%$ \\
\hline Liabilities & $47.2 \%$ & $47.3 \%$ & $46.8 \%$ \\
\hline -out of which Bank loans & $10.7 \%$ & $11.2 \%$ & $11.1 \%$ \\
\hline Subsidies & $8.0 \%$ & $8.4 \%$ & $8.4 \%$ \\
\hline
\end{tabular}

Source: Green report, Ministry of Agriculture and Rural Development of Slovak republic

Table 4. Share of funds in financing new fixed assets in Slovak agriculture

\begin{tabular}{|c|c|c|c|}
\hline & $\mathbf{2 0 1 5}$ & $\mathbf{2 0 1 6}$ & $\mathbf{2 0 1 7}$ \\
\hline Owner`s equity & $64.7 \%$ & $66.5 \%$ & $65.7 \%$ \\
\hline Bank loans & $24.6 \%$ & $25.5 \%$ & $25.6 \%$ \\
\hline Subsidies & $14.7 \%$ & $5.0 \%$ & $2.8 \%$ \\
\hline Other funds & $10.8 \%$ & $7.9 \%$ & $8.7 \%$ \\
\hline
\end{tabular}

Source: Green report, Ministry of Agriculture and Rural Development of Slovak republic

Farmers in Slovakia carried out investment in 2017 from own resources (profit and write offs) and from external resources. Bank loans were the most important external source for investment. Bank loans to agriculture increased annually by $9.6 \%$ in 2017(Table 13). Medium-term (1-5 years) and long-term (more than 5 years) loans grew faster than short-term loans. Growth of loans was supported by low interest rate too. Short-term loans dominate (40,2\% of all bank loans in 2017). The amount of short-term loans is linked to direct payments of the farm, which serve as a collateral. Medium-term and long-term bank loans served to pre-finance or co-finance projects from Rural Development Program (RDP) too.

\subsection{Finance Providers and financial products for farmers}

Slovak agriculture is mainly financed by commercial banks. In 2018 there were 27 banks registered in Slovakia. Of them, four provide a bulk of all credit to farmers (Table 5).

Table 5. List of main banks providing loans to farmers in Slovakia

\begin{tabular}{|c|c|}
\hline Bank & Address \\
\hline Slovenská sporitel'ňa, a.s. & Tomášikova 48, 832 37 Bratislava \\
\hline Tatra banka, a.s. & Hodžovo námestie 3, 811 06 Bratislava \\
\hline Všeobecná úverová banka, a.s. & Mlynské nivy 1, 829 90 Bratislava \\
\hline UniCredit Bank Czech Republic and Slovakia, a.s., & Šancová 1/A, 813 33 Bratislava \\
\hline
\end{tabular}

Source: National bank of Slovakia

UniCredit Bank with the market share of $30 \%$ in the segment of agricultural loans is traditionally the biggest bank for farmers in Slovakia because it is the country's successor of Polnobanka which was set up as a specialized financial institution for farming sector. UniCredit Bank is followed in agricultural loans by Vseobecna uverova banka with market 
share of $25 \%$, Tatra Banka, which has market share of $20 \%$ and Slovenska sporitelna $(10 \%)$.

In addition to bank loans, financial institutions provide to agricultural sector also leasing services and bank guarantees. Loans can be further divided into general loans and specific agricultural loans. General loans are used by all types of clients including farms while specific agricultural loans are created for the use of farmers only. To access general loans farmers can approach all 27 commercial banks registered in Slovakia. Specific agricultural loans are provided by 6 banks.

-Financial products for farmers in Slovakia cover>

$\bullet$ Loans

- General loans

- Specific agricultural loans

-Leasing

-Guarantees

The value of agricultural leasing market is 149 mil. EUR, which is about $20 \%$ of the value of agricultural loan market. Farmers use leasing to finance trucks, combines, tractors, harvesters, and other types of machinery. Machinery serves as a collateral and leasing companies can offer services to farmers with higher risk. The state-owned Slovenská záručná a rozvojová banka (Slovak guarantee and development bank) provides guarantees to commercial banks that extend loans to farmers. In 2017 the share of guarantees on all financial products in Slovak agriculture was less than $2 \%$.

Favourable business conditions after the accession of Slovakia into the EU and rising CAP subsidies play an important role in financing of agriculture in Slovakia. Farming risk has been declining since the joining of the EU in 2004. The accession of the Slovak Republic to the EU in 2004 and the introduction of the CAP in Slovak agriculture led to a decrease in the risk of farming in Slovakia due to enhanced stability of markets and policies. This contributed to an increase in the volume of agricultural loans.

Banks normally provide short term loans in the amount of $100 \%$ of direct payments, in some cases to good costumers $150 \%$ of direct payments that the farm receives. About half of medium-term and long-term loans are used to pre-finance and co-finance RDP 20142020 investment projects.

Long-term loans are used by farmers in Slovakia also to purchase land. Land purchases serve to expand the farm or to buy the land that was rented. Slovak farmers have the highest share of rented land among all the EU member states. For purchase of land some commercial banks provided long-term investment loans up to 15 years. The amount of loan for the purchase of land ranges from $€ 3,000$ to $€ 330,000$ and farms have to contribute with $10-20 \%$ of their own resources. The demand for loans for purchase of land is driven by low interest rates, higher direct payments, and the expectation of increasing of land prices in the future. Price of land was kept low due to significant fragmentation of land ownership and high transaction costs to purchase or rent land. Consolidation of land ownership in the future within a state programme financed by RDP funds or national funds will lead to lower transaction costs at the land market and higher land prices.

Banks offer loans to farmers in Slovakia with flexible interest rates. Interest rates increase with the maturity of loans. Short-term loans are offered with interest rate EURIBOR $+2 \%$ on average, medium-term loans EURIBOR $+2.5 \%$ on average and longterm loans EURIBOR $+3 \%$ on average. Loans to purchase land are characterized by the highest interest rates.

Leasing market is focusing on financing vehicles and passenger cars for farmers. The volume of leasing for farms in Slovakia is 149 mil. EUR in 2018. Main banks providing loans in Slovak agriculture own leasing companies which are active in providing leasing services to farms. 


\subsection{Access to finance in Slovakia: Who suffers?}

Currently the situation on the money and financial market is favourable for farmers. Banks offer loans with relatively low interest rates. In Slovakia, large farms are dominant. They cover $90 \%$ of land and provide $95 \%$ of agricultural production. Generally large farms have no problem to obtain loans, according to representatives of farm associations and banks. Large farms can have loan application rejected if the planned project is too risky. Very specialized farms and farms specializing in animal production are considered riskier than average. Farms that heavily depend on the weather conditions, i.e. farms producing fruits and vegetables are considered riskier too, specifically if insurance is not sufficient. Startups that have no history and inferior collateral are also considered very risky by the banks.

Small farms have the most difficult access to credit in Slovakia. The market is dominated by large farms. Small farms have been created only recently. They do not have sufficient credit history and collateral. Furthermore, small farms and young farmers especially have huge investment needs that require significant amount of loans. Most small farms are the first generation farm. Furthermore, infrastructure in Slovakia, including the structure of suppliers of inputs and purchasers of outputs, banks and provider of services are used to deal with large farms not with small farms which have not existed until 1989. Large farms are significantly helped by high amount of direct payments that they receive. Direct payments are either used to invest or as a collateral for loans. Small farms with low direct payments cannot invest enough from direct payments or have low collateral. The estimated gap in financing of small farms in Slovakia is 100 mil. EUR.

Banks have no specific product for small farms. Some banks do not deal with farms with lower agricultural area than 20 hectares or even 100 hectares due to high transaction costs. Small farms do not pass through their selection criteria. For that reasons small farms receive loans not as businesses but as households only. Long-term loans are also difficult to obtain by farms and have higher interest rates.

Land market imperfections negatively affect credit market. Extreme fragmentation of land ownership hinders the use of land as a collateral. In many cases buildings cannot be used as collateral due to unclear property rights. Low prices of land make land an insufficient collateral for loans.

\section{Conclusions}

The volume of loans in Slovak agriculture is increasing rapidly since 2004. The increase was negatively affected by the economic crisis from 2009-2013. Slovakia has a dual structure of farms. Large farms dominate the sector. Slovak farms have credit constraint especially for long-term loans and in sub-sectors in which Slovak agricultural production is declining (animal production, fruits and vegetables).

Credit market fails to provide sufficient loans to small and young farmers. Banks do not have appropriate financial products for small and young farmers. Small farms in Slovakia are the result of the dissolution of state-owned cooperatives after 1989. They have a short business history and majority of them have relatively low assets and insufficient collateral. Many small farms are not linked to credit markets.

About $17 \%$ of all farms (4 300) are managed by young farmers (less than 40 years). Most of those farms are smaller than 100 ha. Small young farmers have higher demand for loans than other small farmers. The average loan capacity of young small farmers is 150000 EUR.

About 50\% of all loans in Slovakia in 2018 were guaranteed by direct payments. Most banks provide working capital to farms in the amount of annual farm's direct payments. One quarter of all agricultural loans are used for pre-financing or co-financing of RDP 
projects. Interviews confirmed high demand for financial instruments among farmers. In addition to the elimination or reduction of credit constraint, FIs could replace inefficient RDP grants that suffer from high administrative burden, inappropriate timing, low frequency of calls for proposals as well as from lengthy or non-transparent evaluation and monitoring process.

\section{Acknowledgements}

This paper was supported by the project VEGA no. 1/0666/17 with the title Impact of Integration and Globalization on Business Risk in Slovak Agriculture, by the Slovak Research and Development Agency under the contract no. APVV-18-0512 and KEGA no. 041SPU-4/2017 with the title Financial management a business risk in Slovak agriculture.

\section{References}

1. M. Toth, A. Piterkova, P. Serences, Z. Cierna, I. Holubek, Development of Risk and Return of Slovak Crop and Animal Farms. Conference: 10th International Conference on Applied Business Research (ICABR). Madrid, Spain, 1046-1052 (2015)

2. R. Weber, O. Musshoff, Is agricultural microcredit really more risky? Evidence from Tanzania. Agricultural Finance Review 72, 416-435 (2012)

3. T. Million, Fertilizer adoption, credit access, and safety nets in rural Ethiopia. Agricultural Finance Review 74, 290-310 (2014)

4. A. Reyes, R. Lensink, A. Kuyvenhoven, H. Moll, Dynamics of Investment for MarketOriented Farmers in Chile. IDEAS Working Paper Series from RePEc. St. Louis, (2012)

5. P. Ciaian, J. Falkowski, K. d'Artis, Access to credit, factor allocation and farm productivity: Evidence from the CEE transition economies. Agricultural Finance Review 72, 22-47 (2012)

6. J. Swinnen, H. R. Gow, Agricultural Credit Problems And Policies During The Transition To A Market Economy In Central And Eastern Europe. IDEAS Working Paper Series from RePEc; St. Louis, (1997)

7. Agricultural paying agency in Slovakia (2017): Annual report 2016, available at http://www.apa.sk/vyrocne-spravy-ppa

8. Agricultural paying agency in Slovakia (2018): Annual report 2017, available at http://www.apa.sk/vyrocne-spravy-ppa

9. Agricultural paying agency in Slovakia (2019): Annual report 2018, available at http://www.apa.sk/vyrocne-spravy-ppa

10. Agricultural policy institute (2019). Draft report: Revision of Expenditures on Agriculture and Rural Development Expenditure, available at http://www.mpsr.sk/sk/index.php?navID=47\&sID=184\&navID2=1263

11. P. Ciaian, J. Pokrivcak, D. Drabik, Transaction costs, product specialisation and farm structure in Central and Eastern Europe. Post-Communist Economies 21, 191-201, (2009)

12. EIB-FI COMPASS (2019): Survey on financial needs and access to finance of EU agricultural enterprises, available at https://www.ficompass.eu/publication/brochures/survey-financial-needs-and-access-finance-euagricultural-enterprises 
13. EUROPEAN COMISSION, (2014): Slovakia and the CAP. available at: http://ec.europa.eu/agriculture/sites/agriculture/files/policy-perspectives/policybriefs/enlargement/sk_en.pdf

14. EUROPEAN COMISSION, (2016): CAP in your country. available at: http://ec.europa.eu/agriculture/sites/agriculture/files/cap-in-your-country/pdf/sk_en.pdf

15. EUROPEAN COMISSION (2018): Agriculture in the European Union and the Member States - Statistical factsheets, available at https://ec.europa.eu/agriculture/statistics/factsheets_en

16. MARD SR (2016): Green report, available at http://www.mpsr.sk/index.php?navID=122\&id=10906

17. MARD SR (2017): Green report, available at http://www.mpsr.sk/index.php?navID=122\&id=12419

18. MARD SR (2018): Green report, available at http://www.mpsr.sk/index.php?navID=122\&id=13741 